\title{
INCLUSIVE SOCIETY: \\ MERAJUT TOLERANSI BERBANGSA BERBASIS AGAMA, SOSIAL-EKONOMI, DAN POLITIK LOKAL
}

\author{
Muhammad Zaki \\ Sekolah Tinggi Agama Islam (STAI) Yasni Muara Bungo, Jambi \\ muhammadzaki@staiyasnibungo.ac.id
}

\begin{abstract}
The diversity that develop in the earth of Indonesia is sunnatullah and a necessity that cannot be rejected by anyone, whether they like or dislike. As an entity, the Indonesian people should make the diversity as a force in order to achieve the goal and noble ideals of Indonesian nation, is to bring prosperity for all people, both welfare and spiritual, vertical well-being or horizontal. The phenomenon that occurs in some Indonesian society at this time is the depletion of community inclusivism at various levels of life, thus becoming a problem for the integration and wholeness of the nation-state. This fact can be seen from the events that occur in the homeland these days, which feels very exclusive nuances, such as the growing understanding of radicalism, terrorism, religious politicization and intolerant attitudes in addressing a social issue. This happens because of various factors, such as the occurrence of irregularities in religious understanding for some adherents, the existence of political interests, and the existence of socio-economic problems. Therefore, the inclusive understanding of the community needs to be knit again by promoting the spirit of togetherness, openness and tolerance among fellow elements of the nation. This study aims to re-knit the concept of an inclusive Indonesian society and ready to accept the diversity and differences. The development of inclusive society in this study is based on differences in religious, socio-economic, and political perspectives that embraced by Indonesians.
\end{abstract}

Keywords : Inclusive Society, Socio-Economic, Local Politics.

\begin{abstract}
Abstrak
Keberagaman yang berkembang di bumi Indonesia merupakan sunnatullah dan sebuah keniscayaan yang tidak dapat ditolak oleh siapapun, baik yang suka maupun tidak suka. Sebagai sebuah entitas, maka masyarakat Indonesia harus menjadikan keberagaman tersebut sebagai sebuah kekuatan dalam rangka mencapai tujuan dan cita-cita mulia bangsa Indonesia, yaitu menghadirkan kesejahteraan bagi seluruh rakyat, baik kesejahteraan lahir maupun bathin, kesejahteraan vertikal maupun horizontal. Fenomena yang terjadi pada sebagian masyarakat Indoensia saat ini adalah menipisnya inklufisme masyarakat di berbagai level kehidupan, sehingga menjadi persoalan bagi integrasi dan keutuhan berbangsa-bernegara. Kenyataan ini dapat dilihat dari berbagai peristiwa yang terjadi di tanah air akhir-akhir ini, yang sangat
\end{abstract}


terasa nuansa eksklusifnya, seperti berkembangnya paham radikalisme, terorisme, politisasi agama dan sikap-sikap intoleran dalam menyikapi suatu persoalan sosial kemasyarakatan. Hal ini terjadi karena berbagai faktor, diantaranya adalah terjadinya penyimpangan dalam pemahaman keagamaan bagi sebagian pemeluknya, adanya kepentingan politik, serta adanya problematika sosial-ekonomi. Oleh karena itu, paham inklusif masyarakat perlu untuk dirajut kembali dengan mengedepankan semangat kebersamaan, keterbukaan dan toleransi antar sesama elemen bangsa. Penelitian ini bertujuan untuk merajut kembali konsep masyarakat Indonesia yang inklusif serta siap menerima keberagaman dan perbedaan yang ada. Pembangunan masyarakat inklusif dalam penelitian ini berbasiskan pada perbedaan pemahaman keagamaan, sosial-ekonomi dan sudut pandang politik yang dianut oleh masyarakat Indonesia.

Kata kunci: Masyarakat Inklusif, Sosial-Ekonomi, Politik Lokal.

\section{PENDAHULUAN}

Indonesia adalah bangsa yang majemuk dan merupakan anugerah dari sang Pencipta alam semesta. Namun kemajemukan dapat berpotensi menjadi masalah jika tidak dikelola dengan baik. Salah satu masalah berkaitan dengan kemajemukan bangsa Indonesia adalah dalam hal toleransi kehidupan masyarakat. Abad ke-21 Masehi sebagai milenium ketiga merupakan era kebangkitan berbagai pemikiran, diantaranya adalah pemikiran keagamaan yang diikuti dengan maraknya konflik sosial di mana-mana, walaupun agama bukan satu-satunya faktor utama, namun dalam eskalasinya pemikiran keagamaan memainkan peranan penting. Kesetiaan umat terhadap agamanya secara negatif cenderung melahirkan ideologi eksklusif yang dapat melahirkan konflik umat beragama, ${ }^{1}$ khususnya sikap intoleransi antar maupun internalpenganut agama. Praktik keberagamaan yang eksklusif ini telah menggejala di berbagai kalangan umat beragama di dunia, tidak terkecuali di Indonesia. Pola kehidupan keagamaan seperti ini merupakan salah satu ancaman bagi penciptaan integrasi dan kohesi sosial dalam masyarakat yang plural dan multikultural seperti di Indonesia. Hal yang demikian menyulut dampak negatif terhadap masa depan kehidupan berbangsa dan bernegara.

\footnotetext{
${ }^{1}$ Kunawi Basyir, "Pola Kerukunan Antarumat Islam dan Hindu di Denpasar Bali", dalam ISLAMICA: Jurnal Studi Keislaman, Vol. 8 (1), 2013, 1.
} 
Dalam perspektif sosial budaya, agama tidak terlepas dari masyarakat tempat para pemeluk agama setempat berada. Agama berfungsi sebagai sistem pengetahuan dan keyakinan untuk menjalani kehidupan di dunia dan memasuki kehidupan di akherat. Karena fungsi agama seperti itulah, maka agama dianggap sebagai roh dari kehidupan masyarakat. Oleh karena itu, agama dapat menjadi perekat kedamaian, tetapi agama juga dapat menimbulkan ketegangan dan kekerasan sosial. ${ }^{2}$

Pemasalahan toleransi yang terjadi dalam masyarakat juga disebabkan oleh faktor sosial-ekonomi, sebagaimana konflik yang meletus pada bulan Januari 1999 di kota Ambon. Hasil penelitian Basman menyebutkan bahwa interaksi dalam bidang perekonomian menjadi salah satu sumber konflik di Ambon, karena masyarakat (pribumi komunitas Islam-Kristen) di Ambon merasa tergeser dalam kehidupan ekonomi, karena harus bersaing dengan para pendatang Bugis, Buton, Makassar, Jawa, Sumatera, dan lain-lain yang menguasai sebagaian besar sektor perekonomian. ${ }^{3}$ Demikian juga halnya dengan konflik yang terjadi di desa Manis Lor Kabupaten Kuningan Propinsi Jawa Barat. Penelitian yang dilakukan oleh Suwandi Sumartias dan Agus Rahmat pada tahun 2013 menyimpulkan bahwa terdapat pengaruh yang signifikan antara faktor sosial-ekonomi dengan konflik sosial anarkis. ${ }^{4}$

Selain faktor agama dan sosial-ekonomi, politik lokal juga merupakan bagian dari sumber konflik di Indonesia yang mengarah kepada disintegrasi berbangsa dan bernegara. Dinamika politik lokal mempunyai peran penting dalam eskalasi konflik dan intoleransi di tengah masyarakat. Hal ini terjadi karena momen ini merupakan pertemuan berbagai kepentingan politik dan kekuasaan. ${ }^{5} \mathrm{Hal}$ ini penting menjadi perhatian karena tidak bisa dipungkiri

2 Anonim,"Membangun Kerukunan Umat Beragama guna Terwujudnya Hamonisasi Kehidupan Masyarakat dalam Rangka Ketahanan Nasional”, dalam Jurnal Kajian Lemhanas RI, Edisi 14, 2012, 122.

${ }^{3}$ Basman, "Komunikasi Antar Komunitas Agama dalam Membangun Kerukunan (Studi Terhadap Komunitas Islam-Kristen di Kota Ambon Pasca Konflik)", dalam Kontekstualita: Jurnal Penelitian Sosial Keagamaan, Vol. 25 (1), 2009, 57.

${ }^{4}$ Suwandi Sumartias dan Agus Rahmat, "Faktor-Faktor yang Mempengaruhi Konflik Sosial”, dalam Jurnal Penelitian Komunikasi, Vol. 16, (1), 2013, 13.

${ }_{5}$ Muhammad Iqbal Ahnaf, dkk, Politik Lokal dan Konflik Keagamaan: Pilkada dan Struktur Kesempatan Politik dalam Konflik Keagamaan di Sampang, Bekasi, dan 
politik lokal akan terus menjadi bagian penting dari dinamika politik yang akan menentukan kehidupan masyarakat di Indonesia.

Sejarah politik lokal hampir setua umur penjajahan kolonial, desentralisasi kekuasaan, dan administrasi pemerintahan itu sendiri. Bahkan apabila kita menelusuri jauh ke belakang, ke jaman kerajaan yang pernah berdiri dengan megahnya seantero nusantara, para bangsawan mempergunakan politik lokal untuk memperluas wilayah dan kekuasaannya. Sehingga politik lokal dapat dikatakan bukanlah barang baru dalam sejarah pembentukan karakter bangsa dan negara sampai detik tulisan ini dibuat. Sejarah politik lokal terbagi dalam beberapa tahapan masa, yaitu: penjajahan kolonial Belanda; penjajahan kolonial Jepang; pasca kemerdekaan tahun 1945; Republik Indonesia Serikat tahun 1948-1949. ${ }^{6}$

Perhatian terhadap dinamika politik lokal tidak bisa dilepaskan dari konteks desentralisasi di Indonesia. Otonomi daerah justru menjadi pemicu pergeseran konflik dari tingkat nasional ke daerah juga menggeser pola konflik yang bersifat vertikal, antara pemerintah pusat dan daerah, atau pemerintah daerah level provinsi dengan level di bawahnya, akan tetapi sudah bergerak kearah horizontal, antar anggota masyarakat sendiri. Padahal, otonomi daerah bermaksud untuk meredam friksi kepentingan di daerah mengatasnamakan pemerataan pembangunan dan peningkatan kesejahteraan masyarakat lokal di seluruh Indonesia. Eskalasi konflik demikian kuat di daerah mampu menggetarkan kestabilan politik nasional. Konflik komunal, terutama berbasis etnis-religius, berakibat pada semakin menipisnya dinding bangungan negara bangsa (nation state), berganti dengan bangunan identitas etnis ataupun religius yang demikian sempit. ${ }^{7}$

Berdasarkan latar belakang yang telah dikemukakan di atas menunjukkanbahwa persoalan pemahaman terhadap pluralitas pemikiran, baik dalam bidang keagamaan, sosial-ekonomi, maupun politik lokal merupakan

Kupang(Yogyakarta: Program Studi Agama dan Lintas Budaya Sekolah Pasca Sarjana UGM, 2015), 3.

${ }^{6}$ Ratri Istania, Modul Kuliah: Dinamika Politik Lokal (Jakarta: Sekolah Tinggi Ilmu Adnimistarsi LAN, 2009), 8.

${ }^{7}$ Ibid., 47-48. 
tantangan utama yang harus dihadapi oleh masyarakat di Indonesia. Terkait dengan hal ini, kesadaran akan eksistensi pluralitas pemikiran perlu dipahami bersama sebagai realitas alamiah. Kenyataan ini akan membawa konsekuensi logis dalam kehidupan berbangsa dan bernegara, yaitu tuntutan untuk hidup damai antar sesama elemen bangsa. Paradigma dan sikap-sikap yang cenderung eksklusif, dipertaruhkan dalam lingkup multikulturisme di tengah-tengah masyarakat, sehingga paradigma yang bersifat inklusif, toleran, bahkan pemahaman yang moderat menjadi sebuah solusi atas persoalan intoleransi yang dihadapi oleh bangsa Indonesia, sehingga tercipta kehidupan yang harmonis dan toleran berbasis keragaman agama, sosial-ekonomi dan politik lokal.

Penelitian ini bertujuan untuk mengetahui secara komprehensif tentang upaya peningkatan toleransi kehidupan berbangsa dan bernegara melalui pendekatan agama, sosial-ekonomi dan politik lokal. Hasil penelitian ini diharapkan dapat dijadikan referensi dan pedoman bagi pengambil kebijakan maupun stakeholders lainnya dalam rangka menciptakan kehidupan berbangsa yang lebih baik, di tengah pluralitas masyarakat Indonesia dalam berbagai aspek dan tidak dapat dipungkiri eksistensinya.

Penelitian ini merupakan penelitian deskriptif-eksploratif dengan menggunakan pendekatan kualitatif, yang dimaksudkan untuk memberikan deskripsi mengenai fenomena serta kondisi toleransi dan intoleransi kehidupan masyarakatIndonesia. Melalui pendekatan kualitatif, memungkinkan penulis untuk mengelaborasi data yang diperoleh secara komprehensif dan hasil deskripsi menjadi lebih akuntabel.Berdasarkan topik (masalah) yang diangkat, data yang digunakan dalam penelitian ini diperoleh berasal dari dokumentasi dan literatur. Dokumentasi dalam penelitian ini diambil dari literatur-literatur yang representatif dan relevan dengan topik pembahasan. Data yang diperoleh, baik primer maupun sekunder diolah dengan menggunakan pendekatan deskriptif analitis secara komprehensif, sehingga mendapat gambaran yang jelas tentang anatomi toleransi yang berbasis pada pendekatan agama, sosial-ekonomi dan politik lokal. 
6| Muhammad Zaki

\section{KAJIAN TEORITIK}

\section{Masyarakat Inklusif (Inclusive Society)}

Inklusif secara bahasa adalah terbuka. ${ }^{8}$ Kata inklusif berasal dari bahasa Inggris"inclusive" yang berarti sampai dengan atau termasuk. Istilah ini digunakan untuk menunjukkan pada suatu keadaan atausikap yang memandang kelompok lain sebagai bagian atau termasuk dari keadaan tersebut. Selain itu istilah ini juga digunakan untuk menyatakan bahwa sesuatu yang dimiliki seseorang boleh jadi juga terdapat pada orang lain. ${ }^{9}$

Masyarakat inklusif adalah masyarakat yang terbuka terhadap perbedaan-perbedaan yang ada dalam kehidupannya, serta dapat menerimanya sebagai sebuah keniscayaan. Sikap inklusif dalam bermasyarakat didasarkan pada sikap yang mau saling menghargai dalam perbedaan, dan menjadikannya sebagai pengikat dalam membangun harmonisasi hidup bukan justru menonjolkan nilai partikular masing-masing.

\section{Toleransi}

Menurut kamus bahasa Indonesia, toleransimerupakan nomina yang berarti sifat atau sikap toleran. Sedangkan kata toleranmerupakan kata sifat atau adjektiva yang berarti bersifat atau bersikap menenggang(menghargai, membiarkan, membolehkan)pendirian (pendapat, pandangan,kepercayaan, kebiasaan, kelakuan,dan sebagainya) yg berbeda atau bertentangandengan pendirian sendiri. ${ }^{10}$ Toleransi berasal dari bahasa latin tolerantia, berarti kelonggaran, kelembutan hati, keringanan dan kesabaran. Secara umum istilah toleransi mengacu pada sikap terbuka, lapang dada, suka rela dan kelembutan. ${ }^{11}$

Dalam Deklarasi Prinsip-Prinsip Toleransi UNESCO dinyatakan bahwa toleransi adalah rasa hormat, penerimaan, dan penghargaan atas keragaman budaya dunia yang kaya, berbagai bentuk ekspresi diri, dan cara-cara menjadi

8 Rofiq Nurhadi, dkk, "Dialektika Inklusivisme dan Eksklusivisme Islam: Kajian Semantik Terhadap Tafsir Alquran tentang Hubungan antar Agama”, dalam Kawistara, Vol. 3, (1), 2013, 59.

${ }^{9}$ Zain Abidin, "Islam Inklusif: Telaah atas Doktrin dan Sejarah", dalam Humaniora, Vol. 4, (2), 2013, 1277.

${ }^{10}$ Tim Penyusun, Kamus Bahasa Indonesia (Jakarta: Pusat Bahasa Departemen Pendidikan Nasional, 2008), 1538.

${ }^{11}$ Casram, "Membangun Sikap Toleransi Beragama dalam Masyarakat Plural", dalam Wawasan: Jurnal Ilmiah Agama dan Sosial Budaya, Vol. 1, (2), 2016, 188. 
manusia. Toleransi adalah kerukunan dalam perbedaan. ${ }^{12}$ Sedangkan Sullivan, Pierson dan Marcus menjelaskan toleransi sebagai a willingness to put up with those things one rejects or opposes, yakni "kesediaan untuk menghargai, menerima atau menghormati segala sesuatu yang ditolak atau ditentang oleh seseorang". ${ }^{13}$

Toleransi dalam penelitian ini adalah kesediaan menghargai, menghormati dan menerima keberadaan orang lain yang diaktualkan dalam sikap dan perilaku baik perorangan maupun kelompok orang tanpa ada paksaan, dengan sikap maupun perilaku.Toleransi harus didukung oleh cakrawala pengetahuan yang luas, bersikap terbuka, dialog, kebebasan berpikir dan beragama. Pendek kata toleransi setara dengan sikap positif, dan menghargai orang lain dalam rangka menggunakan kebebasan asasi sebagai manusia.

\section{Politik Lokal}

Politik lokal secara harfiah adalah bagian dari suatu sistem politik yang dijalankan oleh suatu Negara. Konteks lokal dalam hal ini menyiratkan pada pemaknaan heterogenitas masyarakat lokal (daerah) yang memiliki kesejarahan, situasi batin dan psikologis yang berbeda. Kondisi tersebut tentu memberikan kontribusi pada praktek politik di daerah sebagai cara memanifestasikan atau praktek dari paradigma yang terbangun. ${ }^{14}$

Secara umum politik lokal tidak dapat dilepaskan dari konteks politik nasional atau sistem politik yang dianut oleh suatu negara. Politik lokal merupakan dinamika institusi-institusi politik di daerah dalam mengaktualisasikan interaksi dalam penyelenggaran pemerintahan dan kehidupan bermasyarakat dan memfungsikan peran-peran yang dilaksanakan oleh masing-masing institusi tersebut. Dalam konteks ini maka institusi-institusi politik lokal adalah dapat dikategorikan menjadi supra struktur politik dan infra struktur politik. Supra struktur politik yang dimaksud adalah pemerintah daerah

\footnotetext{
${ }^{12}$ Ahsanul Khalikin dan Fathuri (ed.), Toleransi Beragama di Daerah Rawan Konflik (Jakarta: Puslitbang Kehidupan Keagamaan Kemenag RI, 2016), 12.

${ }^{13}$ Ibid.

14 Bappenas, Politik Lokal Terhadap Efektifitas Pemerintahan Daerah (Jakarta: Ditpolkom Bappenas RI, 2014), 8.
} 
8 | Muhammad Zaki

dan Dewan Perwakilan Rakyat (DPRD). Infra struktur politik dalam hal ini meliputi partai politik, kelompok kepentingan dan media massa. ${ }^{15}$

\section{Merajut Toleransi Berbasis Agama, Sosial-Ekonomidan Politik Lokal}

Toleransi dalam kehidupan berbangsa dan bernegara bagi masyarakat Indonesia merupakan sebuah keniscayaan dalam berbagai aspek. Hal ini mengingat pluralitas masyarakat yang tidak dapat dipungkiri. Dalam realitasnya, kemajemukan ini juga dapat menjadi penyebab perpecahan di antara masyarakat yang dapat mengancam keutuhan berbangsa dan bernegara. Bagi masyarakat Indonesia, kondisi ini memerlukan pendekatan khusus untuk menciptakan toleransi berbangsa serta menghindari intoleransi, sehingga terwujud masyarakat yang aman, tentram dan sejahtera, baik jasmani maupun rohani.

Agama merupakan kebutuhan ideal bagi umat manusia dan memiliki peran yang sangat menentukan dalam kehidupan. Bahkan manusia tidak dapat hidup dengan sempurna tanpa melalui bimbingan agama. Peranan agama menjadi sangat penting ketika agama dianut sekelompok manusia yang terkait dengan kegiatan pemenuhan kebutuhan hidupnya. Dalam kondisi semacam itulah agama telah menjadi kultural manusia. Sehingga agama dan masyarakat memiliki keterkaitan yang bersifat timbal balik.

Dalam masyarakat yang plural dari segi agama, sebagaimana di Indonesia, jika terjadi konflik sosial, faktor agama seringkali dimanfaatkan oleh pihak-pihak yang konflik untuk menciptakan solidaritas kelompok sekaligus sebagai pemicu. Dengan demikian, di kalangan umat beragama konflik sosial dapat berkembang menjadi konflik atau intoleransi keagamaan.

Berdasarkan hasil kajian Badan Litbang dan Diklat Kementerian Agama yang kemudian disosialisasikan oleh H.M. Atho Mudzhar melalui tulisannya dalam buku berjudul "Merayakan Kebhinnekaan Membangun Kerukunan” ada beberapa faktor penyebab ketidakrukunan atau yang dapat menimbulkan konflik atau intoleransi. Faktor-faktor dimaksud meliputi "faktor keagamaan" dan "faktor non keagamaan". Faktor-faktor keagamaan selain doktrin

\footnotetext{
${ }^{15}$ Ibid., 9.
} 
keagamaan, yaitu: penyiaran agama; pendirian rumah ibadat; bantuan keagamaan luar negeri; perkawinan antar pemeluk agama yang berbeda; pengangkatan anak; pendidikan agama; perayaan hari besar keagamaan; perawatan dan pemakaman jenazah; penodaan agama; kegiatan kelompok sempalan; dan transparansi informasi keagamaan. Sedangkan faktor non keagamaan, meliputi: kesenjangan ekonomi; kepentingan politik dan perbedaan nilai budaya. ${ }^{16}$

Sikap toleran terhadap aspek atau faktor-faktor keagamaan tertentu yang dilakukan seseorang maupun kelompok orang terhadap umat beragama lain, dapat ditingkatkan dan dikembangkan untuk menangkal kemungkinan timbulnya konflik serupa pada masa mendatang, sehingga daerah yang semula dikategorikan sebagai "rawan konflik" diharapkan tingkat kerawanannya berkurang. Sebaliknya, jika sikap intoleransi berkembang di suatu daerah maka dapat menjadi faktor pemicu yang akan mendorong daerah rawan konflik menjadi daerah konflik.

Toleransi beragama tidak berarti bahwa seseorang yang telah mempunyai keyakinan kemudian berpindah atau merubah keyakinan-nya untuk mengikuti dan berbaur dengan keyakinan atau peribadatan agama-agama lainnya (sinkretisme); tidak pula dimaksudkan untuk mengakui kebenaran semua agama/ kepercayaan; melainkan bahwa ia tetap pada suatu keyakinan yang diyakini kebenarannya, serta memandang benar keyakinan orang lain, sehingga dalam dirinya terdapat kebenaran yang diyakininya sendiri menurut suara hatinya sendiri yang tidak diperoleh atas dasar paksaan orang lain atau diperoleh dari pemberian orang lain.

Masyarakat multikultural terpola oleh keragaman budaya termasuk keragaman agama. Di dalam perjalanannya, agama-agama yang muncul dalam masyarakat multikultural kemudian dipahami oleh umatnya. Di antara mereka, ada yang memahaminya secara rasional an sich dan ada pula yang memahaminya secara irrasional atau mistis. Dampak heterogenitas agama ini bisa memunculkan konflik di antara umat berbeda agama. Toleransi sangat

\footnotetext{
${ }^{16}$ Fathuri (ed.), Toleransi,4.
} 
dibutuhkan untuk menciptakn keseimbangan dan kohesi sosial dalam masyarakat multikutral. Untuk menciptakan sikap toleransi beragama yang proposional dalam masyarakat multikultural perlu menumbuhkan sikap inklusifdalam berteologi. Sikap inklusifini mutlak diperlukan tanpa kompromi agar mereka bisa menjalankan toleransi beragama dengan baik. Jika sikap inklusifini tidak dimiliki, maka toleransi terhadap agama orang lain hanya akan sebatas basa-basi atau, sekalipun toleransi beragama bisa dilakukan, kecenderungan menyampur seluruh ajaran beragama atau menafikan ajaran agama dan digantikan dengan kepentingan nilai-nilai kemanusiaan yang bersifat umum dan sekuler akan muncul.

Pemasalahan intoleransi yang terjadi dalam masyarakat dapat juga disebabkan oleh faktor sosial-ekonomi, beberapa penelitian terdahulu menjelaskan bahwa terdapat pengaruh yang signifikan antara faktor sosialekonomi dengan konflik sosial. Selain faktor agama dan sosial-ekonomi, politik lokal juga merupakan bagian dari sumber konflik dan intoleransi di dalam kehidupan bermasyarakat yang mengarah kepada disintegrasi berbangsa dan bernegara. Dinamika politik lokal mempunyai peran penting dalam eskalasi konflik dan intoleransi di tengah masyarakat. Hal ini terjadi karena momen ini merupakan pertemuan berbagai kepentingan politik dan kekuasaan.Hal ini penting menjadi perhatian karena tidak bisa dipungkiri politik lokal akan terus menjadi bagian penting dari dinamika politik yang akan menentukan kehidupan masyarakat di Indonesia.

Pada dasarnya, dalam keragaman terkandung kekayaan yang membuat hidup semakin berarti. Tetapi dalam keragaman juga terbuka peluang untuk saling bersinggungan atau bahkan konflik. Motif ekonomi, politik, atau kekuasaan menjadikan pluralitas sering diposisikan sebagai komoditas untuk meraih tujuan yang tidak beradab. Maka, atas nama perbedaan, antaranggota dalam satu kelompok dapat saling ejek, saling serang, bahkan saling memusnahkan. Realitas semacam inilah yang sering terjadi di Indonesia. Konflik 
etnis, kelompok, atarsuku, dan ataragama menjadi persoalan serius yang masih sering meletup setiap waktu. ${ }^{17}$

Ketika pluralitas merupakan sebuah realitas, maka membangun kesadaran terhadap inklusifisme dalam berbagai aspek, termasuk sosial-ekonomi dan politik merupakan dimensi yang sangat penting. Sebab, kesadaran terhadap inklusifisme inilah yang seharusnya menjadi landasan dalam bersikap, berinteraksi, dan membangun relasi sosial secara luas. Tanpa kesadaran demikian, setiap perbedaan dinilai sebagai ancaman yang harus ditundukkan. Pihak yang berbeda dinilai sebagai lawan, bukan sebagai kawan dialog yang setara. Kata kuncinya adalah membangun kesadaran tentang inklusif.

Dalam membangun kesadaran tersebut perlu sebuah upaya intensif. Upaya intensif tersebut bisa berupa pendidikan multikultural bagi masyarakat yang dilakukan dalam semua jenjang pendidikan, serta melibat seluruh komponen bangsa, sesuai dengan kapasitasnya masing-masing. Masyarakat yang telah memiliki wawasan tentang multikulturalisme dan memiliki cara pandang yang inklusif terhadap agama, sosial dan politik, maka dengan penuh keyakinan bahwa kehidupan yang harmonis akan tercipta.

\section{PENUTUP}

Masyarakat inklusif adalah masyarakat yang terbuka terhadap perbedaanperbedaan yang ada dalam kehidupannya dalam berbagai aspek, serta dapat menerimanya sebagai sebuah keniscayaan. Sikap inklusif dalam bermasyarakat didasarkan pada sikap yang mau saling menghargai dalam perbedaan, dan menjadikannya sebagai pengikat dalam membangun harmonisasi kehidupan berbangsa dan bernegara. Kesadaran terhadap inklusifisme merupakan landasan dalam bersikap, berinteraksi, dan membangun relasi sosial secara luas, sehingga tercipta kehidupan yang lebih baik dalam bingkai toleransi kebangsaan. Dengan kesadaran ini, akan terealisasi semangat kehidupan berbangsa dan sebagai syarat bagi terlaksananya keadilan dan kesejahteraan bersama.

${ }^{17}$ Eko Sumadi, "Membangun Keberagmaan Inklusif Melalui Konseling Multikultural", dalam Konseling Religi: Jurnal Bimbingan Konseling Islam, Vol. 7, No. 1, Juni 2016, hal. 15. 
12 | Muhammad Zaki

\section{DAFTAR PUSTAKA}

Abidin, Zain. "Islam Inklusif: Telaah atas Doktrin dan Sejarah".Dalam Humaniora, Vol. 4 (2), 2013.

Ahnaf, Muhammad Iqbal, dkk.Politik Lokal dan Konflik Keagamaan: Pilkada dan Struktur Kesempatan Politik dalam Konflik Keagamaan di Sampang, Bekasi, dan Kupang. Yogyakarta: Program Studi Agama dan Lintas Budaya Sekolah Pasca Sarjana UGM, 2015.

Anonim. "Membangun Kerukunan Umat Beragama guna Terwujudnya Hamonisasi Kehidupan Masyarakat dalam Rangka Ketahanan Nasional". Dalam Jurnal Kajian Lemhanas RI, Edisi 14, 2012.

Bappenas.Politik Lokal Terhadap Efektifitas Pemerintahan Daerah. Jakarta: Ditpolkom Bappenas RI, 2014.

Basman. “Komunikasi Antar Komunitas Agama dalam Membangun Kerukunan (Studi Terhadap Komunitas Islam-Kristen di Kota Ambon Pasca Konflik)".Dalam Kontekstualita: Jurnal Penelitian Sosial Keagamaan, Vol. 25, (1), 2009.

Basyir, Kunawi. "Pola Kerukunan Antarumat Islam dan Hindu di Denpasar Bali”.Dalam ISLAMICA: Jurnal Studi Keislaman, Vol. 8 (1), 2003.

Casram. "Membangun Sikap Toleransi Beragama dalam Masyarakat Plural".Dalam Wawasan: Jurnal Ilmiah Agama dan Sosial Budaya, Vol. 1 (2), 2016.

Istania, Ratri.Modul Kuliah: Dinamika Politik Lokal. Jakarta: Sekolah Tinggi Ilmu Adnimistarsi LAN, 2009.

Khalikin, Ahsanul dan Fathuri (ed.).Toleransi Beragama di Daerah Rawan Konflik. Jakarta: Puslitbang Kehidupan Keagamaan Kemenag RI, 2016.

Nurhadi, Rofiq, dkk. "Dialektika Inklusivisme dan Eksklusivisme Islam: Kajian Semantik Terhadap Tafsir Alquran tentang Hubungan antar Agama".Dalam Kawistara, Vol. 3 (1), 2013.

Sumadi, Eko. "Membangun Keberagmaan Inklusif Melalui Konseling Multikultural".Dalam Konseling Religi: Jurnal Bimbingan Konseling Islam, Vol. 7 (1), 2016.

Sumartias, Suwandi dan Agus Rahmat. "Faktor-Faktor yang Mempengaruhi Konflik Sosial". Dalam Jurnal Penelitian Komunikasi, Vol. 16 (1), 2013. 
13 | Muhammad Zaki

Tim Penyusun.Kamus Bahasa Indonesia. Jakarta: Pusat Bahasa Departemen Pendidikan Nasional, 2008.

Jurnal Hukum dan Ekonomi Syari'ah, Vol. 06 | Nomor 2 